Check for updates

Cite this: RSC Adv., 2020, 10, 22487

Received 23rd March 2020

Accepted 3rd June 2020

DOI: $10.1039 / \mathrm{d} 0 \mathrm{ra02678f}$

rsc.li/rsc-advances

\section{Synthesis of indium oxide microparticles using aerosol assisted chemical vapour deposition $\uparrow$}

\author{
Firoz Alam (D) ab and David J. Lewis (D) *a \\ Microparticles of indium oxide $\left(\mathrm{In}_{2} \mathrm{O}_{3}\right)$ are deposited on glass substrates at $500{ }^{\circ} \mathrm{C}$ using aerosol assisted \\ chemical vapour deposition (AACVD). The structural, morphological and optical properties of the as- \\ deposited particles are reported.
}

Indium oxide $\left(\operatorname{In}_{2} \mathrm{O}_{3}\right)$ is a promising wide bandgap n-type semiconductor with good optical transparency in the visible region and has drawn significant interest in the field of photovoltaics, ${ }^{\mathbf{1}, 2}$ thin film transistors, ${ }^{3}$ photodetectors ${ }^{4}$ and gas sensors. ${ }^{5}$ Doping with other metals (such as $\mathrm{Sn}, \mathrm{Mo}, \mathrm{Zr}, \mathrm{Ga}, \mathrm{Ti}$ and $\mathrm{Ta}$ ) is possible in order to modify the properties of $\operatorname{In}_{2} \mathrm{O}_{3}$, whilst retaining optical transparency in the visible region of the electromagnetic spectrum. Examples of these widely used doped materials include (i) tin-doped indium oxide (ITO), which is a well known transparent conducting oxide (TCO) has an optical bandgap of $3.4 \mathrm{eV}$, good chemical stability and excellent adhesion to the substrate, widely used in optoelectronic devices such as light emitting $\operatorname{diodes}^{6}$ and solar cells ${ }^{7}$ (ii) recently, molybdenum-doped $\operatorname{In}_{2} \mathrm{O}_{3}$ (IMO) has been reported as an durable alternative to the commercially dominant ITO. ${ }^{8}$ IMO has shown higher conductivity and increased infrared transparency than ITO with the same carrier density. This makes IMO a more suitable and low cost alternative material for device applications as much thinner films of IMO can produced with properties equal to or better than ITO of the same carrier concentration; (iii) Zr-doped indium oxide, which has been used as a transparent electrode in perovskite/silicon tandem devices, which results in the improvement of the power conversion efficiency from $23.3 \%$ to $26.2 \%$; $^{1}$ and (iv) Ga-doped indium oxide which has been used in phase change memory devices. ${ }^{9}$

Several deposition techniques have been used to produce $\mathrm{In}_{2} \mathrm{O}_{3}$ thin films such as atomic layer deposition, ${ }^{10}$ molecular beam epitaxy, ${ }^{11}$ pulsed laser deposition, ${ }^{12}$ spin coating, ${ }^{2}$ metal organic chemical vapour deposition ${ }^{\mathbf{1 3}}$ and aerosol assisted chemical vapour deposition. ${ }^{\mathbf{1 4 , 1 5}}$ The latter technique is useful

\footnotetext{
${ }^{a}$ Department of Materials, The University of Manchester, Oxford Road, Manchester, M13 9PL, UK. E-mail: david.lewis-4@manchester.ac.uk

${ }^{b}$ Department of Chemistry, The University of Manchester, Oxford Road, Manchester, M13 9PL, UK

$\dagger$ Electronic supplementary information (ESI) available: Experimental section, instrumentation, full description of thin film deposition using AACVD and EDX analysis. See DOI: 10.1039/d0ra02678f
}

as it is simple, low cost, single step and used in the industry for assembly line glass coating. Maeng et al. reported $\operatorname{In}_{2} \mathrm{O}_{3}$ films using $\mathrm{Et}_{2} \mathrm{InN}(\mathrm{TMS})_{2}$ as a liquid precursor and $\mathrm{H}_{2} \mathrm{O}$ in the temperature range of $225-250{ }^{\circ} \mathrm{C}^{\mathbf{1 0}} \mathrm{Kim}$ et al. has used spin coating to deposit $\mathrm{In}_{2} \mathrm{O}_{3}$ using indium chloride as precursor and annealed at $400{ }^{\circ} \mathrm{C} .^{3}$ In both the cases a poorly crystalline $\mathrm{XRD}$ pattern is reported. Basharat et al. has reported the deposition of $\operatorname{In}_{2} \mathrm{O}_{3}$ film at $550{ }^{\circ} \mathrm{C}$ on glass substrate from the dual-source AACVD reaction of $\mathrm{Me}_{3}$ In and $\mathrm{ROH}\left(\mathrm{R}=\mathrm{CH}_{2} \mathrm{CH}_{2}\right.$ $\left.\mathrm{NMe}_{2}, \mathrm{CH}\left(\mathrm{CH}_{3}\right) \mathrm{CH}_{2} \mathrm{NMe}_{2}, \mathrm{C}\left(\mathrm{CH}_{3}\right)_{2} \mathrm{CH}_{2} \mathrm{OMe}, \mathrm{CH}_{2} \mathrm{CH}_{2} \mathrm{OMe}\right)$ in toluene. ${ }^{14}$ The chosen ligands are less air/moisture sensitive and have increased solubility, but the preparation of precursor ligands are time consuming ( $24 \mathrm{~h}$ reaction), multi-stepped and require low temperatures $\left(-78^{\circ} \mathrm{C}\right)$. Yang et al. reported a onestep aqueous solvothermal method for the synthesis of highly crystalline and nearly monodisperse $\operatorname{In}_{2} \mathrm{O}_{3}$ nanocrystals. ${ }^{16}$ Seo et al. reported the preparation of colloidal, highly crystalline and size controlled $\operatorname{In}_{2} \mathrm{O}_{3}$ nanoparticles from thermal decomposition of the $\operatorname{In}(\text { acac })_{3}$ precursor in oleylamine. ${ }^{17}$ These latter methods yield highly crystalline and monodisperse nanoparticles, but are quite time consuming and not suitable for mass production of $\operatorname{In}_{2} \mathrm{O}_{3}$. A comparison table of AACVD and other reported methods for producing indium oxide has been incorporated into the ESI. $\uparrow$ The structural phase stability, optical properties, electronic structure and high pressure behaviour of $\operatorname{In}_{2} \mathrm{O}_{3}$ has been studied by Karazhanov et al. using first-principles density functional theory (DFT) calculations in three different space group symmetries $I 2_{1} 3, I a \overline{3}$ and $R \overline{3}$. It is found that $\mathrm{In}_{2} \mathrm{O}_{3}$ with space group $I a \overline{3}$ undergoes a pressureinduced phase transition to the R3 phase at ca. 3.8 GPa. For $\mathrm{In}_{2} \mathrm{O}_{3}$ the magnitudes of the absorption and reflection coefficients with these space group symmetries are small and in the energy range of $0-5 \mathrm{eV}$, indicating that these phases are transparent. ${ }^{18}$

In this paper we report the deposition of transparent indium oxide microparticles on glass substrates using aerosol assisted chemical vapour deposition (AACVD) from a single precursor solution. AACVD is an ambient pressure CVD technique which is simple, cost-effective, proceeds in a single step and is suitable 
for the production of large area thin films on a range of substrates, and has been used for the deposition of wide range of semiconducting materials such as $\mathrm{MAPBr},{ }^{19} \mathrm{Cs}_{2} \mathrm{SnI}_{6}{ }^{20}$ $\mathrm{MoS}_{2}{ }^{21}$ Cr-doped $\mathrm{MoS}_{2},{ }^{22} \mathrm{SnS}^{23}$ and copper zinc tin sulfide (CZTS). ${ }^{24}$ Solubility of the precursor molecules in a solvent is required in order to obtain high quality thin films. A number of indium precursors have been used to deposit high quality $\operatorname{In}_{2} \mathrm{O}_{3}$ thin films and whilst current precursor design is functional, none of them are entirely satisfactory and have certain disadvantages, ${ }^{\mathbf{1 4}}$ for example, [In- $\left.\left(\mathrm{OCMe}\left(\mathrm{CF}_{3}\right)_{2}\right)_{3}\left(\mathrm{H}_{2} \mathrm{~N}^{t} \mathrm{Bu}\right)\right]$ and $\left[\mathrm{Me}_{2}-\right.$ In( $\left.\left.\mathrm{OC}\left(\mathrm{CF}_{3}\right)_{2} \mathrm{CH}_{2}-\mathrm{NHMe}\right)\right]$ contain fluorine, which results in fluorine contamination in $\operatorname{In}_{2} \mathrm{O}_{3}$ films. ${ }^{25,26}\left[\operatorname{In}(\text { thd })_{3}\right]$ (thd $=$ 2,2,6,6-tetramethylheptane-3,5-dionate) was synthesised and added to dichloromethane $\left(\mathrm{CH}_{2} \mathrm{Cl}_{2}\right)$, toluene and tetrahydrofuran (THF) separately, but in all cases a fine suspension is formed which, upon standing for $1 \mathrm{~h}$, is sedimented. ${ }^{15}$ Indium halides are known for their poor solubility in non-coordinating organic solvents and often rapidly disproportionate to $\mathrm{In}^{\mathrm{II}}$ or In ${ }^{\text {III }}$ halide complexes with treatment of coordinating solvents. ${ }^{27}$ Keeping the solubility of precursor in mind, we have used for the first time a mixture of polar aprotic solvents to completely dissolve InI to obtain a clear transparent precursor solution for the deposition of $\operatorname{In}_{2} \mathrm{O}_{3}$ on glass substrates using AACVD.

The precursor solution was obtained by dissolving indium iodide (InI) powder in a mixture of anhydrous $\mathrm{N}, \mathrm{N}$-dimethylformamide (DMF) and acetonitrile $(1: 1, \mathrm{v} / \mathrm{v})$ with stirring for $1 \mathrm{~h}$ at $70{ }^{\circ} \mathrm{C}$. Aerosols were generated from this solution using an ultrasonic humidifier, which were then transported using a stream of argon gas (250 sccm) into a hot wall reactor containing cleaned glass substrates at a temperature of $500{ }^{\circ} \mathrm{C}$. After decomposition of the precursor a transparent film comprised of $\operatorname{In}_{2} \mathrm{O}_{3}$ microparticles is obtained. The asdeposited materials were characterised using powder X-ray diffraction (p-XRD) in the range of $10^{\circ}<2 \theta<70^{\circ}$ (Fig. 1). Reflections from the (211), (222), (400), (411), (431), (440), (611)

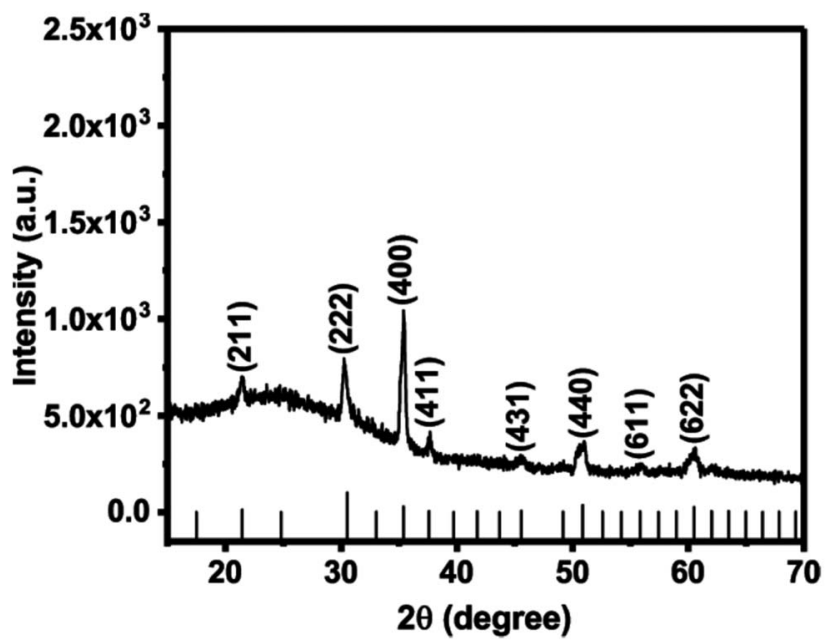

Fig. 1 PXRD pattern of $\operatorname{In}_{2} \mathrm{O}_{3}$ microparticles deposited by AACVD on glass substrates at $500{ }^{\circ} \mathrm{C}$. The black sticks represent the theoretical powder diffraction pattern of cubic $\ln _{2} \mathrm{O}_{3}$ (ICCD file no. 00-0060416). and (622) Bragg planes of cubic $\operatorname{In}_{2} \mathrm{O}_{3}$ were observed at $2 \theta=$ $21.49^{\circ}, 30.58^{\circ}, 35.46^{\circ}, 37.68^{\circ}, 45.69^{\circ}, 51.03^{\circ}, 55.99^{\circ}$ and $60.67^{\circ}$ respectively (ICCD no. 00-006-0416, space group Ia $\overline{3}$ with $a=$ $10.11 \AA)$. The reflection indexed to the (400) plane is dominant, which indicates a preferred orientation of growth along this direction under these conditions. ${ }^{8}$

The Raman spectrum of the $\operatorname{In}_{2} \mathrm{O}_{3}$ microparticle film was collected using $514 \mathrm{~nm}$ laser excitation. Scattering peaks at 130, 551 and $1371 \mathrm{~cm}^{-1}$ were observed (Fig. 2). The peak around $130 \mathrm{~cm}^{-1}$ is assigned to the $\mathrm{A}_{\mathrm{g}}^{(1)}$ vibrational mode and peak at 551 and $1371 \mathrm{~cm}^{-1}$ are ascribed to the phonon vibrational modes of cubic $\operatorname{In}_{2} \mathrm{O}_{3}$. These values are consistent with those reported in literature. ${ }^{28-30}$ The remaining peaks around 1100 and $1600 \mathrm{~cm}^{-1}$ are assigned to carbon which may arise from decomposition of solvent. ${ }^{31}$

The surface morphology of the as-deposited material was investigated using scanning electron microscopy (SEM) in secondary electron mode. Spherical microparticles are uniformly and randomly distributed over the substrate (Fig. 3(a)). Fig. 3(b) shows the distribution of indium (In) over an interrogated area of $c a .15 \times 11 \mu \mathrm{m}$ confirmed by energy dispersive X-ray (EDX) mapping at an acceleration voltage of 10 kV. Fig. 3(c) shows a histogram which summarises the size distribution of $\operatorname{In}_{2} \mathrm{O}_{3}(N=65)$. The average diameter of an $\operatorname{In}_{2} \mathrm{O}_{3}$ particle is $368 \pm 120 \mathrm{~nm}$. The mechanisms of indium oxide particle growth and resulting particle sizes have been discussed in literature. Maensiri et al. reported that the average particle size of $\operatorname{In}_{2} \mathrm{O}_{3}$ increases with increasing the calcination temperature. ${ }^{32}$ Ayeshamariam et al. reported that crystallite sizes derived from XRD increases with increasing annealing temperature and that the band gap energy of these particles also scales linearly as a function of annealing temperature. It was not expected to be a quantum confinement effect as the particle sizes studied ( $c a .30 \mathrm{~nm}$ ) were all an order of magnitude greater than the exciton Bohr radius of $\operatorname{In}_{2} \mathrm{O}_{3}(\mathrm{ca} .3 \mathrm{~nm}) .^{33}$ Elemental

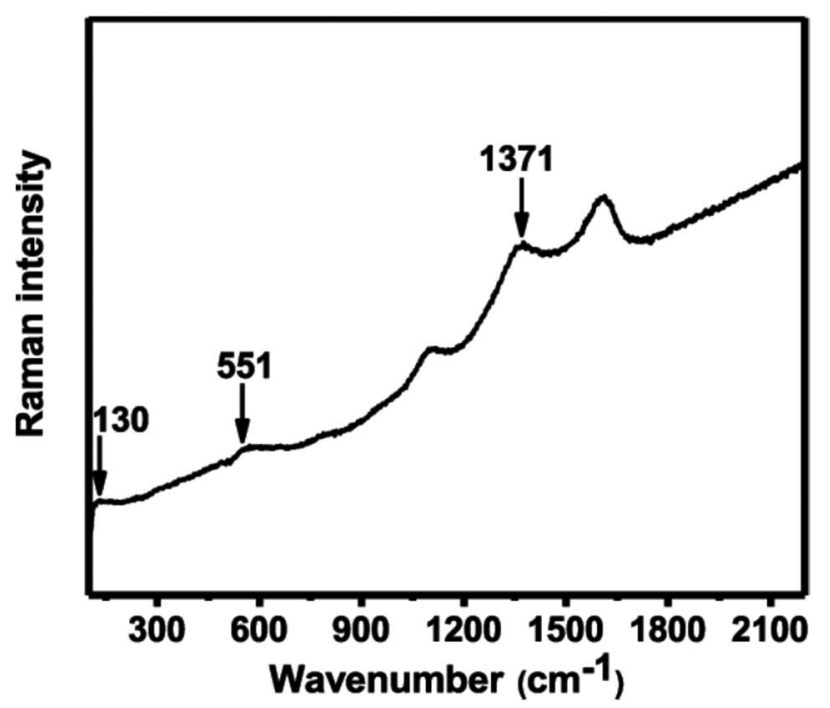

Fig. 2 Raman spectrum of $\ln _{2} \mathrm{O}_{3}$ microparticles deposited by AACVD on a glass substrate at $500{ }^{\circ} \mathrm{C}$. 

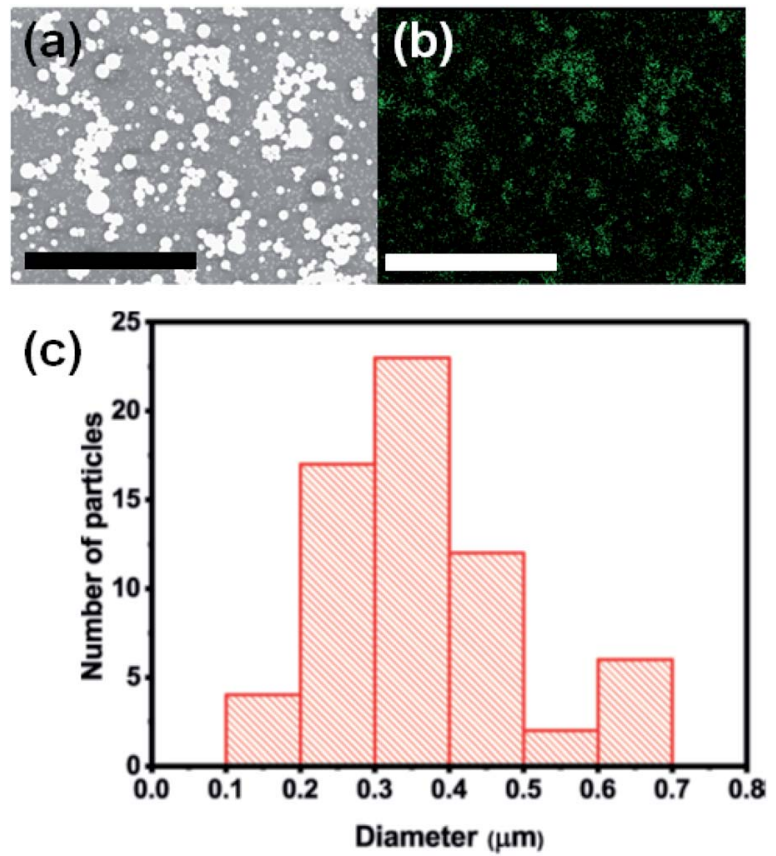

Fig. 3 Characterisation at the microscale using electron microscopy. (a) Secondary electron (SE) SEM image, (b) spatially resolved EDX spectrum mapping of In emission over the same area and (c) histogram of $\mathrm{In}_{2} \mathrm{O}_{3}$ microparticles deposited by AACVD on a glass substrate at $500{ }^{\circ} \mathrm{C}(N=65)$. The scale bar in (a) and (b) corresponds to $7 \mu \mathrm{m}$ in each case.

composition of our $\operatorname{In}_{2} \mathrm{O}_{3}$ microparticle film was performed using EDX. The EDX spectrum and atomic percent of the elements present in $\operatorname{In}_{2} \mathrm{O}_{3}$ film are shown in Fig. S1 and $\mathrm{S} 2, \dagger$ giving a clear indication of the presence of In in the film.

The optical properties of as-deposited thin film of $\operatorname{In}_{2} \mathrm{O}_{3}$ microparticle was investigated by UV-Vis-NIR transmittance in the wavelength range $300-900 \mathrm{~nm}$. The as-deposited $\operatorname{In}_{2} \mathrm{O}_{3}$ shows over $80 \%$ transmittance in the wavelength range of $400-$ $900 \mathrm{~nm}$ (Fig. 4), which is comparable to previous reports. ${ }^{10}$ The inset of Fig. 4 shows an absorbance spectrum of $\operatorname{In}_{2} \mathrm{O}_{3}$ microparticles revealing strong optical absorbance in the ultraviolet region of the spectrum. Estimation of optical bandgap of $\operatorname{In}_{2} \mathrm{O}_{3}$ microparticle thin film from Tauc plot (described in full in the ESI Section S5†) gives a direct band gap value of $3.53 \mathrm{eV}$ (Fig. S3†). Given the band gap value of $3.53 \mathrm{eV}$, the $\operatorname{In}_{2} \mathrm{O}_{3}$ produced by this method and under these conditions is thus a wide band gap semiconductor. By visual inspection it is observed that the $\operatorname{In}_{2} \mathrm{O}_{3}$ film deposited on glass substrate is colourless and transparent to visible light. ${ }^{3,34}$

In summary, a simple, cost-effective, and single step aerosol assisted chemical vapour deposition (AACVD) technique has been used for the synthesis of optically transparent spherical $\mathrm{In}_{2} \mathrm{O}_{3}$ microparticles on glass substrates. Powder XRD patterns and Raman scattering confirm the crystallinity of as-deposited $\operatorname{In}_{2} \mathrm{O}_{3}$ microparticles with a preferred orientation along the (400) plane. Inspection of surface morphology by secondary electron SEM shows that the as-deposited $\operatorname{In}_{2} \mathrm{O}_{3}$ microparticles are spherical with an average diameter of $368 \pm 120 \mathrm{~nm}(N=65)$

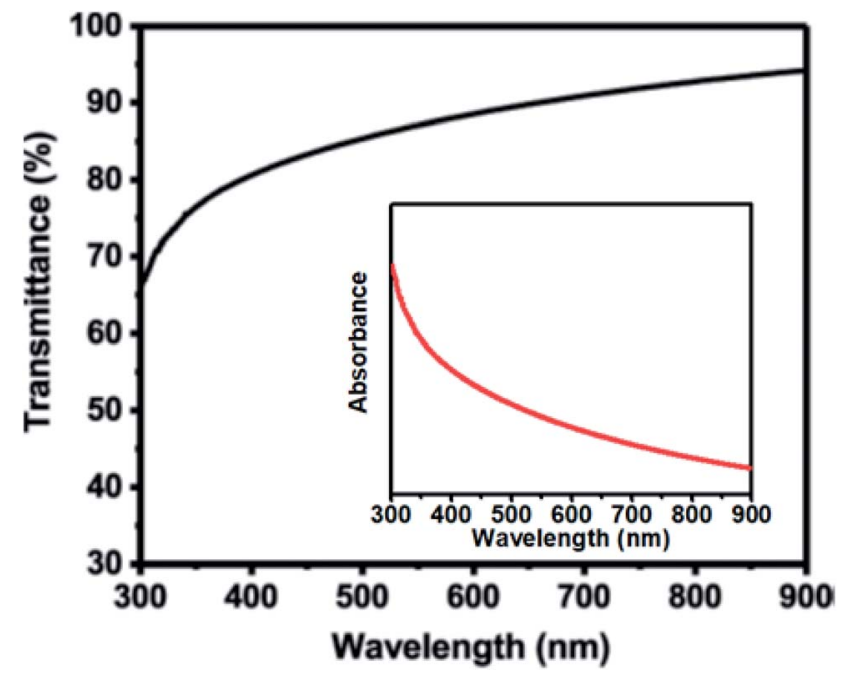

Fig. 4 Optical transmittance spectrum of $\ln _{2} \mathrm{O}_{3}$ microparticles deposited by AACVD technique on a glass substrate at $500^{\circ} \mathrm{C}$. Inset: absorbance spectrum of as-deposited $\ln _{2} \mathrm{O}_{3}$ microparticles.

and are uniformly and randomly distributed over the substrate. EDX spectroscopy gives a clear indication of the presence of In on the substrate. The UV-Vis-NIR spectroscopy of as-deposited $\mathrm{In}_{2} \mathrm{O}_{3}$ microparticle film show over $80 \%$ transmittance in the wavelength range of 400-900 $\mathrm{nm}$ and strong optical absorbance in the ultraviolet region of the spectrum with an estimated direct bandgap value of $3.53 \mathrm{eV}$ from a Tauc plot. Optical data thus suggest that bandgap value of $3.53 \mathrm{eV}$ does not fall in the band gap range for semiconductors, and hence materials produced by this method are wide band gap semiconductors. Thus the AACVD method we report produces indium oxide from a soluble carbon-free precursor with potential for scale-up.

\section{Conflicts of interest}

The authors declare no conflicts of interest.

\section{Acknowledgements}

The authors would like to acknowledge funding from UK EPSRC grant number EP/R020590/1.

\section{Notes and references}

1 E. Aydin, M. De Bastiani, X. Yang, M. Sajjad, F. Aljamaan, Y. Smirnov, M. N. Hedhili, W. Liu, T. G. Allen, L. Xu, E. Van Kerschaver, M. Morales-Masis, U. Schwingenschlögl and S. De Wolf, Adv. Funct. Mater., 2019, 29, 19017411901751.

2 S. Yoon, S. J. Kim, H. S. Kim, J. S. Park, I. K. Han, J. W. Jung and M. Park, Nanoscale, 2017, 9, 16305-16312.

3 H. S. Kim, P. D. Byrne, A. Facchetti and T. J. Marks, J. Am. Chem. Soc., 2008, 130, 12580-12581.

4 S.-Y. Han, G. S. Herman and C.-h. Chang, J. Am. Chem. Soc., 2011, 133, 5166-5169. 
5 L. G. Bloor, J. Manzi, R. Binions, I. P. Parkin, D. Pugh, A. Afonja, C. S. Blackman, S. Sathasivam and C. J. Carmalt, Chem. Mater., 2012, 24, 2864-2871.

6 R. Begum, X. Y. Chin, M. Li, B. Damodaran, T. C. Sum, S. Mhaisalkar and N. Mathews, Chem. Commun., 2019, 55, 5451-5454.

7 J.-H. Kim, H.-J. Seok, H.-J. Seo, T.-Y. Seong, J. H. Heo, S.-H. Lim, K.-J. Ahn and H.-K. Kim, Nanoscale, 2018, 10, 20587-20598.

8 J. E. Swallow, B. A. Williamson, S. Sathasivam, M. Birkett, T. J. Featherstone, P. A. Murgatroyd, H. J. Edwards, Z. W. Lebens-Higgins, D. A. Duncan and M. Farnworth, Mater. Horiz., 2020, 7, 236-243.

9 S. L. Wang, C. Y. Chen, M. K. Hsieh, W. C. Lee, A. H. Kung and L. H. Peng, Appl. Phys. Lett., 2009, 94, 113503-113505.

10 W. J. Maeng, D.-w. Choi, K.-B. Chung, W. Koh, G.-Y. Kim, S.-Y. Choi and J.-S. Park, ACS Appl. Mater. Interfaces, 2014, 6, 17481-17488.

11 O. Bierwagen, M. E. White, M.-Y. Tsai and J. S. Speck, Appl. Phys. Lett., 2009, 95, 262105-262107.

12 E. Tarsa, J. English and J. Speck, Appl. Phys. Lett., 1993, 62, 2332-2334.

13 C. Y. Wang, V. Cimalla, H. Romanus, T. Kups, G. Ecke, T. Stauden, M. Ali, V. Lebedev, J. Pezoldt and O. Ambacher, Appl. Phys. Lett., 2006, 89, 011904.

14 S. Basharat, C. J. Carmalt, S. A. Barnett, D. A. Tocher and H. O. Davies, Inorg. Chem., 2007, 46, 9473-9480.

15 D. Pugh, L. G. Bloor, S. Sathasivam, I. P. Parkin and C. J. Carmalt, Eur. J. Inorg. Chem., 2011, 2011, 1953-1960.

16 J. Yang, C. Li, Z. Quan, D. Kong, X. Zhang, P. Yang and J. Lin, Cryst. Growth Des., 2008, 8, 695-699.

17 W. S. Seo, H. H. Jo, K. Lee and J. T. Park, Adv. Mater., 2003, 15, 795-797.

18 S. Z. Karazhanov, P. Ravindran, P. Vajeeston, A. Ulyashin, T. G. Finstad and H. Fjellvåg, Phys. Rev. B: Condens. Matter Mater. Phys., 2007, 76, 075129.

19 D. J. Lewis and P. O'Brien, Chem. Commun., 2014, 50, 63196321.
20 J. C.-R. Ke, D. J. Lewis, A. S. Walton, B. F. Spencer, P. O'Brien, A. G. Thomas and W. R. Flavell, J. Mater. Chem. A, 2018, 6, 11205-11214.

21 A. A. Tedstone, D. J. Lewis, R. Hao, S.-M. Mao, P. Bellon, R. S. Averback, C. P. Warrens, K. R. West, P. Howard, S. Gaemers, S. J. Dillon and P. O'Brien, ACS Appl. Mater. Interfaces, 2015, 7, 20929-20934.

22 D. J. Lewis, A. A. Tedstone, X. L. Zhong, E. A. Lewis, A. Rooney, N. Savjani, J. R. Brent, S. J. Haigh, M. G. Burke and C. A. Muryn, Chem. Mater., 2015, 27, 1367-1374.

23 P. Kevin, D. J. Lewis, J. Raftery, M. A. Malik and P. O'Brien, J. Cryst. Growth, 2015, 415, 93-99.

24 K. Ramasamy, M. A. Malik and P. O'Brien, Chem. Sci., 2011, 2, 1170-1172.

25 L. A. Mîinea, S. Suh and D. M. Hoffman, Inorg. Chem., 1999, 38, 4447-4454.

26 T.-Y. Chou, Y. Chi, S.-F. Huang, C.-S. Liu, A. J. Carty, L. Scoles and K. A. Udachin, Inorg. Chem., 2003, 42, 6041-6049.

27 S. P. Green, C. Jones and A. Stasch, Angew. Chem., Int. Ed., 2007, 46, 8618-8621.

28 C. Kranert, R. Schmidt-Grund and M. Grundmann, Phys. Status Solidi RRL, 2014, 8, 554-559.

29 K. L. Chitturi, A. Yaramma, R. Merugu, R. Dachepalli and J. Kandhadi, Adv. Nanopart., 2016, 5, 114-122.

30 C. K. Latha, M. Raghasudha, Y. Aparna, M. Ramchander, D. Ravinder, K. Jaipal, P. Veerasomaiah and D. Shridhar, Mater. Res., 2017, 20, 256-263.

31 A. Dychalska, P. Popielarski, W. Franków, K. Fabisiak, K. Paprocki and M. Szybowicz, J. Mater. Sci., 2015, 33, 799805.

32 S. Maensiri, P. Laokul, J. Klinkaewnarong, S. Phokha, V. Promarak and S. Seraphin, J. Optoelectron. Adv. Mater., 2008, 10, 161-165.

33 A. Ayeshamariam, M. Bououdina and C. Sanjeeviraja, Mater. Sci. Semicond. Process., 2013, 16, 686-695.

34 O. Bierwagen, Semicond. Sci. Technol., 2015, 30, 024001. 